\title{
Influence of early thermic and photoperiodic control on growth and smoltification in Atlantic salmon (Salmo salar)
}

\author{
Jean-Louis Gaignon and Lö̈c Quémener \\ IFREMER, Laboralonire Poinsms, H.P. 7o, 2.g28o Plmzané, France.
}

Received March 20, 1991; accepted June 30, r992.

Gaignon J.-L., L. Quémener. Aquat. Lizing Resour., 1992, 5, 185-195.

\begin{abstract}
Atlantic salmon juveniles were subjected to a precocious (day 104 after first feeding) photoperiodic (P) and thermic ( $\mathrm{T}$ ) control. After rearing the fry at $16^{\circ} \mathrm{C}$, constant $(16$ hours of light and 8 hours of darkness, $\left.16^{\circ} \mathrm{C}\right)(\mathrm{C})$ and shortened simulated natural $\mathrm{S}$ photoperiod and temperature regimes were used in a factorial experimental design until transfer to seawater. The growth obtained with constant (C) regimes was better than with $S$ regimes. In all cases, we observed very early (day 141, mid-Junc) a clear segregation of the population into two different subpopulations. Among the conditions, all the differences between the upper and lower modes were growth-dependent. We observed different developmental trends of the gill $\left(\mathrm{Na}^{+}-\mathrm{K}^{+}\right)$-ATPase activity: the $\mathrm{S}$ regime gave a very progressive increase of the enzymatic activity, while we had a rapid decrease after a first phase of increase with a constant photoperiod. The absolute levels of the gill $\left(\mathrm{Na}^{+}-\mathrm{K}^{+}\right)$-ATPase activity were slightly lower than those observed in one year-old smolts. However, they are quite similar to those of upper-mode lish that have a good salinity tolerance. After transfer to seawater, fish subjected to shortencd simulated temperature and photoperiod had the lowest mortality and osmotic disturbance (after 48 hours and 3 weeks). Although the freshwater phase generally lasts more than 15-17 months for this species in a natural environment, we concluded that it is possible to obtain a good salinity tolerance after 7-8 months, with shorlened simulated natural photoperiod and temperalure regimes, in spite of the absence of a real smoltification; these regimes, howcver, must be applied during the "dynamic" presmolting phase when the growth is intense.
\end{abstract}

Keywords: Photoperiod, temperature, $0^{+}$smolts, Atlantic salmon.

Effet d'un contrôle précoce de la température et de la photopériode sur la croissance et la smoltification du saumon atlantique (Salmo salar).

Résumé

Des juvéniles de saumons atlantiques (Salmo salar) ont été soumis précocement (104 jours après la première distribution alimentaire) à un contrôle de la photopériode $(\mathrm{P})$ et de la température $(\mathrm{T})$. Lc premier alevinage s'est déroulé à $16^{\circ} \mathrm{C}$; puis des régimes de photopériode et températurc constants (C) $\left(16\right.$ heures de jours et 8 heures de nuit, $\left.16^{\circ} \mathrm{C}\right)$ et simulés naturels raccourcis (S) ont été étudiés à partir d'un plan expérimental factoriel appliqué jusqu'au transfert en mer. La croissance obtenue est meilleure avec les régimes constants (C) qu'avec les régimes simulés (S). Nous avons obtenu très tôt (jour 141, à la mi-juin), et dans tous les cas, une ségrégation de la population en deux sous-groupes. Les différences enregistrées entre les modes haut et bas sont toutes liées à la croissance. L'activité dc la $\left(\mathrm{Na}^{+}-\mathrm{K}^{+}\right)$-ATPase branchiale évoluc differemment en fonction des cas: le régime à photopériode simulée (S) permet une augmentation progressive de l'activité enzymatique alors que dans le cas où la photopćriode est constante unc rapide diminution de l'activité fait suite à une phase d'augmentation. Les niveaux absolus de la $\left(\mathrm{Na}^{+}-\mathrm{K}^{+}\right)$-ATPase branchiale sont légèrement inférieurs à ccux observés sur des smolts de 1 an. Cependant, ils sont voisins de ceux de juvéniles de saumons appartenant au mode haut d'une population (smolts potentiels) qui ont une bonne tolérance aux salinités élevécs. 
Après un transfert en mer, les poissons soumis au régime $S$ ont une moindre mortalité, un déséquilibre osmotique plus faible. Bien que la phase de vie en eau douce se déroule généralement en $15-17$ mois pour celte espece, en conditions naturelles, nous concluons qu'il est possible d'obtenir une bonne tolérance à la salinité aprés 7-8 mois, si l’on applique des régimes de photopérinde el températurc simulés naturels raccourcis et ceci en l'absence d'une réclle smoltilication; ces régimes doivent cependant être utilisés durant une phase dynamique de présmoltilication. Iorsque la croissance est forle.

Mots-clés : Photupériode, température, smolts $0^{*}$, sáumon atlantique.

\section{INTROIUCTION}

The biological cycle of Atlantic salmon (Salmo salar) includes two phases that occur in different environments: river and ocean. At a given time of its river life, the young salmon undergoes deep physiological modifications, including a progressive adaptation to seawater, before initiating its downstream migration, generally occurring in spring. This phenomenon is known as the "smoltification" process, abundantly described in the literature (see review Bosuf, 1992). The duration of the freshwater phase is variable and depends mainly upon the temperature regimes (Hoar, 1988). In the most favourable conditions, this froshwater phase takes 15 to 17 months in wild populations.

The exploitation of the species by aquaculture techniques (cage rearing and ranching opcrations) has been tremendously increasing over the past ten years, and represents to date a considerable economic value. For obvious cconomic reasons, special attention has been given to the possibilities of reducing the duration of this freshwater phase in order to reduce the cost of the smolts. These attempts included the use of geothermal effluents to stimulate the growth (lsaksson, 1985); the use, in Chile, of salmon eggs issued from northern hemisphere broodstocks permitted a smoltification to be obtained during the southern hemisphere spring, allowing the transfer of the fish to seawater after a 10-11 month freshwater rearing period (Bcuf and Médina, 1990). From a more general point of vicw, this objective became a major preoccupation of the industry (Simpson, 1985), stimulating a considerable amount of scientific works. Rescarch approaches included a possible hormonal control of smoltification (Bocuf et al., 1990a), and, more frequently, the effect of environmental parameters on growth and smoltification (Johnston and Saunders, 1981; Saunders et al., 1985; Clarke et al., 1985; McCornick et al., 1987; Stefansson et al., 1988; Villareal et al., 1988; Duston and Saunders, 1990; Saunders and Harmon, 1990; Duston et al., 1991).

The natural climatic conditions prevailing in France allow a rapid growth (Prouzet and Jćzćquel, 1983; Gaignon, 1987) and would make possible the production of accelerated smolts at a moderate cost. It is thus essential in these conditions to obtain a "satisfactory" smoltification, allowing a precocious transfer to seawater.

The smoltification process is a complex combination of modifications (see revicw from Bœuf, 1987; Hoar, 1988), depending upon an endogenous rhythm synchronized by variations of several cnvironmental factors (Eriksson and Lundqvist, 1982; Duston and Saunders, 199()). The effects of photoperiod and tcmperature (Clarke et al., 1981; Johnston and Saunders, 1981) or of photoperiod alone (Clarke et al., 1985; McCormick, 1987; Stefansson, 1989; Bjornsson et al., 1989) have been intensively investigated. This last parameter is sometimes described as a factor allowing an ultimate "accomplishment" of smoltification (Stcfansson et al., 1989; Duston, 1990); Mc Cormick (1987), Saunders ef al. (1989) indicate that the smoltification process can be completely achieved only after an exposure of several months to increasing daylight. Brauer (1982) showed in coho salmon that the growth has an influence on the effects of the photoperiod.

Almost all these studies have been carried out during the normal smoltification period, generally after December (Saunders et al., 1985; McCormick et al., 1987; Stefansson et al., 1989; Duston and Saunders, 1990), and rarcly sooner (Saunders et al., 1987; McCormick et al., 1987; Stefansson et al., 1991). Very often thcy have been using constant photophases, compared to controls using the simulated local photoperiod or a 24 hours continuous daylight. Works being done at carlier stages of the biological cycle were designed to describe the appearance of a bimodal structure of the population during the first autumn, characteristic of the species (Saunders and Henderson, 1988; Villarreal et al., 1988; Stewart et al., 1990; Skilbrei, 1991). The only works concerning the effects of a momentancous modification of the photophase, using a stable daylight regime in autumn, were carried out by Saunders et al. (1989) and more recently by Saunders and Harmon (1990). To our knowledge, no existing papers have been published on the effects of photoperiod on smoltification in completely artificially controlled light conditions since fecundation. The purpose of the present experiment was to study the effect of several photoperiod and temperature regimes, applied at a very early stage on subsequent growth and smoltification. 


\section{MATERIAL AND METHODS}

Since January 31st 1989, 3075 fry (Norwegian strain from Matre Aquaculture Research Station) were reared in Swedish type tanks $(1 \times 1 \mathrm{~m})$ at the IFREMER (Institut français pour l'exploitation de la mer) experimental facilitics in Brest. During the fry-stage period, the temperature was constant $\left(16 \pm 0.5^{\circ} \mathrm{C}\right)$ and the photoperiod was a constant $16 \mathrm{~L} / 8 \mathrm{D}$ (light/dark) regime. They werc automatically fed on an extruded IFREMER diet (Gaignon, 1987).

The experimental phase began on May 17th, 1989 (day 106 after first feeding). 2500 fish with a mean

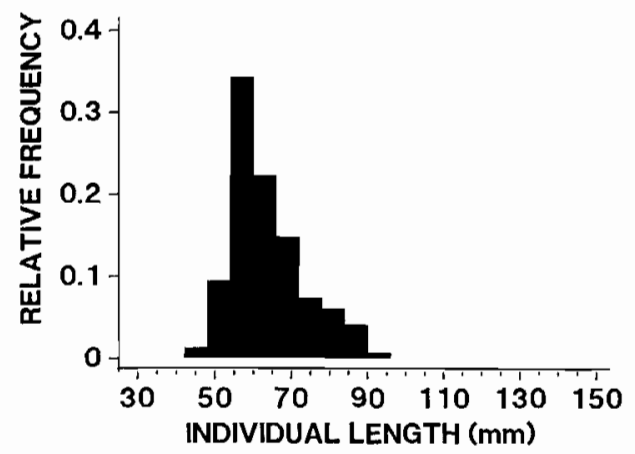

Figure 1. - Length frequency distribution of the fish at the beginning of the experiment (day 106 after first feeding).

weight of $3.49 \mathrm{~g} \mathrm{(} \mathrm{fig} \mathrm{1),} \mathrm{issued} \mathrm{from} \mathrm{the} \mathrm{initial} \mathrm{popula-}$ tion (mortality of $5.8 \%$ during the preliminary phase of the experiment) were randomly and equally distributed in 10 tanks. 2 photoperiodic [i.e. one constant (CP): $16 \mathrm{~L} / 8 \mathrm{D}$ and a natural shortened simulated one (SP)] and 2 thermic [i.e. one constant (CT) $16^{\circ} \mathrm{C}$ and a local shortened simulated one (ST)] regimes were applied in a factorial replicated experimental design. Moreover, an additional temperature regime [with a final decrease from August 13th (D 195) after an initial constant temperature $\left.\left(16^{\circ} \mathrm{C}\right)\right](\mathrm{CDT})$ was realized with each photoperiodic regime, without replicate (fig. 2). The illumination with a fluorescent "True lite" tube $(20 \mathrm{~W})$ and an incandescent $25 \mathrm{~W}$ lamp provides an intensity of 60-80 lux at the surface of the water. No twilight periods were provided. The fluorescent light was switched on 15 minutes after the ignition of the incandescent lamp. The lights were switched off the opposite way. The duration of the fluorescent illumination expressed the day length. The fish were automatically fed on an extruded SSI diet; the pellet-size used is the one defined by Gaignon (1987); the daily feeding rate was based on temperature. The daily feeding duration was equal to the daily photophase.

When the length frequency distribution showed a bimodality, the fish of each tank were graded (July 24th) and fish inferior to the size of $90 \mathrm{~mm}$ were discarded. Before grading, 80-100 fish/tank were weighed (to the nearest $0.1 \mathrm{~g}$ ) and measured (to the nearest $1 \mathrm{~mm}$ ) every 12-14 days. After grading, the same procedure was performed on the 25 July, 8 August, 6 September, 25 September (except for CP). After seawater transfer, a total weight and counting were performed. Throughout the experiment, the mortality was recorded daily.

The smoltification was monitored by measurement of the gill $\left(\mathrm{Na}^{+}-\mathrm{K}^{+}\right)$-ATPase activity (Bouf and Harache, 1982), analyzed on 3 fish until August 11 th and after, on 4-6 fish sampled every 10 days, using fish with an individual size quite similar to the mean length of those of a given tank. The methods for sampling and analyses were already described by Lasserre et al. (1978).

The salinity tolerance test was performed by a direct scawater transfer $(35 \%)$, without tank change, at fortnightly intervals for the two replicates. The osmotic pressure and chlorides were analyzed respectively on a Ruebling osmometer and on a radiometer chloridometer, on fish sampled 48 hours and 3 weeks (only in the case of the first replicate transferred) after seawater transfer. These data, added with the gill $\left(\mathrm{Na}^{+}-\mathrm{K}^{+}\right)$-ATPase activity, are considered to be a good criterion for seawater adaptation of Atlantic salmon according to previous results (Bœuf and Harache, 1982).

When the length segregations are clearly established, the observed population structures were normalized with the NORMSEP program (Tomlinson, 1970; after Hasselblad, 1966) which determines the mean and the standard deviation of the different subgroups with an iterative method.

The condition factor was calculated with the following expression $\mathrm{K}=100 \mathrm{~W} / \mathrm{L}^{3}$, where $\mathrm{W}$ and $\mathrm{L}$ are respectively the individual weight and length of a given fish.

The specilic growth rate was calculated with the expression: $1 / n\left(\log W_{f^{-}} \log \mathrm{W}_{i}\right) \times 100$ where $n, \mathrm{~W}_{i}$ and $W_{f}$ are respectively the number of days, the initial and final weight.

In the following text, a "condition" will define a particular experimental treatment combination given to the fish of one tank and will be characterized by a couple of levels of each of the factors, for example: $\mathrm{CP} \times \mathrm{SP}$.

Until the beginning of the temperature decrease, for the statistical analysis, we combined the CDT data with those of CT which had the same temperature (i.e. until D195 three replicates were used for this regime).

Standard deviations are given with the mean value on the figures. The influence of the different conditions were studied on the bimodal population with a Kruskall-Wallis H test (Sachs, 1984). On the normalized subgroups, the different parameters including the limit threshold between the two subgroups were compared with a two-way ANOVA and Scheffe's multiple range test (Sachs, 1984). This type of analysis is also used, after grading, to compare the influence of the 


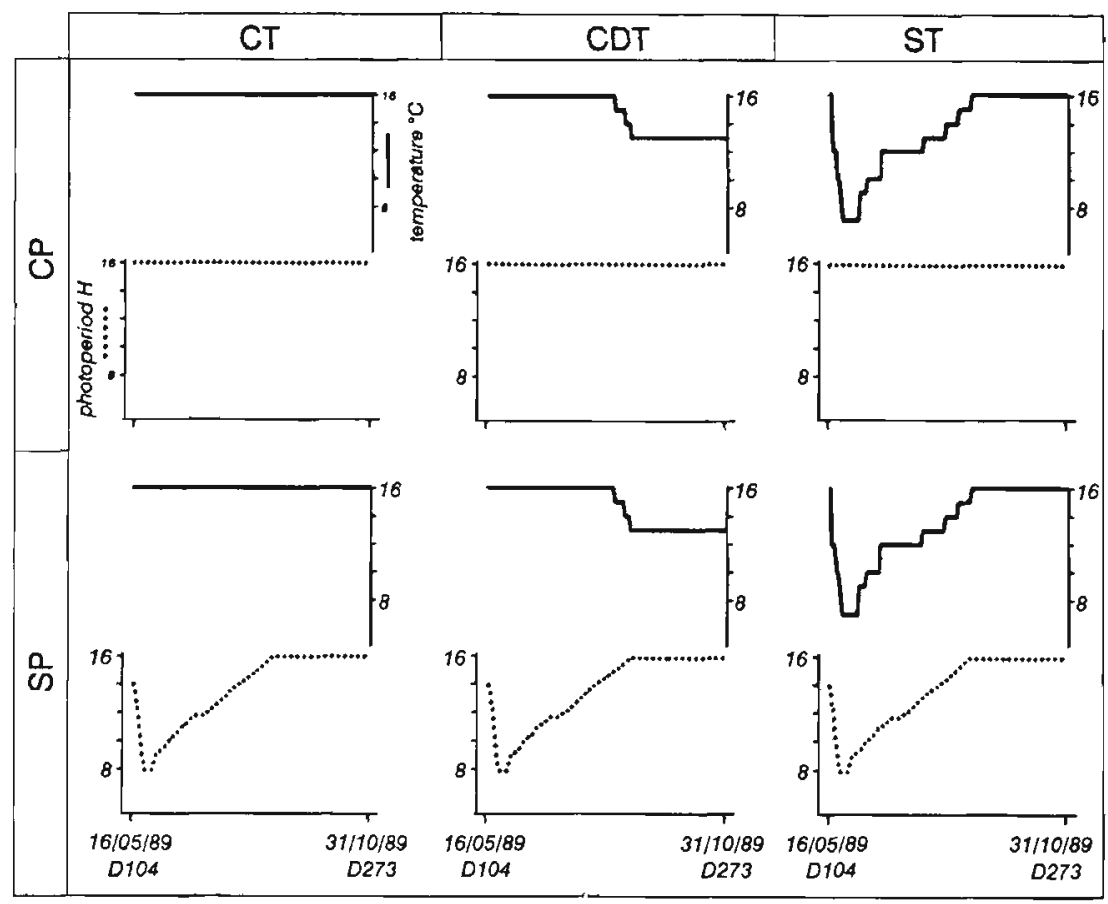

Figure 2. - Temperature $\left({ }^{\circ} \mathrm{C}\right.$ ) and photoperiod (hours) regimes for the different conditions. T: temperature, P: photoperiod, C: constant, S: simulated, CDT: initial constant temperature.

conditions and regimes on length and weight. A significant levcl of $p<0.05$ is used to establish statistically significant differences. For each date, the valucs of ATPase (expressed in $\mu \mathrm{m}$ Pimg Prot. ${ }^{-1} \mathrm{~h}^{-1}$ ), osmotic pressure and chlorides were compared with a Kruskall-Wallis $\mathrm{H}$ test. The ATPase evolution of each tank is characterized by the linear regression giving the higher correlation cocfficient.

\section{RESUITS}

\section{Survival, growth, condition factor}

During the experiment, the mortality was nil in all tanks until transfer to seawater. From the very beginning of the experiment, the treatments studied affected the instantaneous growth rate: the groups reared under constant regimes (temperature and photoperiod) showed a higher growth rate than those observed with variable regimes during the first 22 days of the experiment (table 1). Then the population, initially showing a unimodal structure (fig. 1), evolved towards a typical bimodal length frequency distribution (fig. 3). Bimodality appeared earlier under a $16^{\circ} \mathrm{C}$ constant temperature regime [CT and CDT on June $21 \mathrm{st}$, at D14l after first fecding (fig. 3)]. On July 20th (DI70), before the first grading, the proportion of fish of the upper mode subgroup (UM) of the normalized population was photoperiod-dependent (table 2); however, the limit threshold between the two modes was higher for groups subjectcd to constant regimes (temperature and photoperiod) (table 2). The growth observed before the first grading (D170, July 20) was different according to the conditions: fish from the groups CPCT showed larger mean sizes and weights than

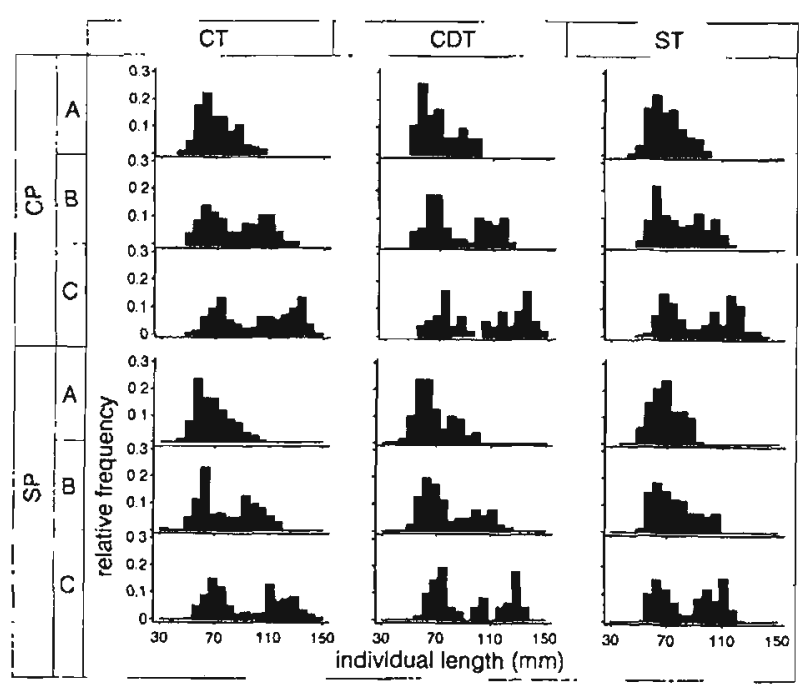

Figure 3. - Length frequency distribution (cumulated replicate) before grading for the different experimental conditions. T: temperaturc, P: photoperiod, C: constant. S: simulated. For each one of these $\Lambda: 26$ May 1989, B: 21 June 1989, C: 19 July 1989. 
Table 1. - Growth rate (mean in \%/day) during the first 22 days of the experiment ( $\mathrm{T}=$ temperature, $\mathrm{P}=$ photoperiod, $\mathrm{C}=$ constant, $\mathrm{S}=$ simulated). For cach condition and each factor () the same letter represents a homogencous group. NS: non significant. (1): data combined with initial constant temperature (CDT). (2): ANOVA gives significant differences but it is impossible to classify the regimes with Scheffe's multiple range test.

\begin{tabular}{|c|c|c|c|}
\hline $\begin{array}{c}\text { Growth rate } \\
(\%)\end{array}$ & $\begin{array}{l}\text { Constant } \\
\text { temperature } \\
\text { CT (1) }\end{array}$ & $\begin{array}{c}\text { Simulated } \\
\text { temperature } \\
\text { ST }\end{array}$ & $\begin{array}{c}\text { Photoperiod } \\
\text { P (2) }\end{array}$ \\
\hline $\begin{array}{l}\text { Simulated } \\
\text { photoperiod SP } \\
\text { Simulated } \\
\text { photoperiod SP }\end{array}$ & $\begin{array}{l}2.69 a \\
\pm 0.20 \\
2.09 a b \\
\pm 0.09\end{array}$ & $\begin{array}{l}1.76 b \\
\pm 0.01 \\
1.57 b \\
\pm 0.21\end{array}$ & $\begin{array}{r}2.32 \\
\pm 0.25 \\
1.88 \\
\pm 0.15\end{array}$ \\
\hline Temperature $T$ & $\begin{array}{l}2.39(a) \\
\pm 0.16 \\
p<\end{array}$ & $\begin{array}{r}1.66(b) \\
\pm 0.10 \\
0.01\end{array}$ & $\begin{array}{c}\text { Interaction } \\
\quad \mathrm{NS}\end{array}$ \\
\hline
\end{tabular}

Table 2. - Influence of thermic $(\mathrm{T})$ and photoperiodic $(\mathrm{P})$ regimes (C: constant, S: simulated) on length frequency distribution parameters before grading. The mean \pm standard errors are given. For each factor and parameter, the same letter represents a homogeneous group. (1) and (2): see table 1 .

\begin{tabular}{|c|c|c|c|c|}
\hline Parameter & CT (1) & ST & $\mathrm{CP}$ & SP \\
\hline \multirow{2}{*}{$\begin{array}{l}\text { Percentage of the normali- } \\
\text { zed upper mode sub- } \\
\text { group (UM) (see text for } \\
\text { explanation) }\end{array}$} & $\begin{array}{r}53.5 \\
\pm 2.0\end{array}$ & $\begin{array}{r}54.5 \\
\pm 0.5\end{array}$ & $\begin{array}{l}56.4 a \\
\pm 1.2\end{array}$ & $\begin{array}{l}51.4 b \\
\pm 1.3\end{array}$ \\
\hline & \multicolumn{2}{|c|}{ NS } & \multicolumn{2}{|c|}{$p<0.05$} \\
\hline \multirow{2}{*}{$\begin{array}{l}\text { Percentage of fish }>90 \mathrm{~mm} \\
\text { after grading }\end{array}$} & $\begin{array}{r}47.3 \\
\pm 2.5\end{array}$ & $\begin{array}{r}43.2 \\
\pm 2.1\end{array}$ & $\begin{array}{r}49.8 \\
\pm 1.8\end{array}$ & $\begin{array}{r}41.6 \\
\pm 1.5\end{array}$ \\
\hline & \multicolumn{2}{|c|}{ NS } & \multicolumn{2}{|c|}{$p<0.01(2)$} \\
\hline \multirow{2}{*}{$\begin{array}{l}\text { Limit threshold between } \\
\text { normalized LM (lower } \\
\text { mode) and UM sub- } \\
\text { groups (mm) }\end{array}$} & $\begin{array}{l}91.1 a \\
\pm 1.6\end{array}$ & $\begin{array}{r}84.8 b \\
\pm 2.0\end{array}$ & $\begin{array}{r}91.4 \\
\pm 1.7\end{array}$ & $\begin{array}{r}85.7 \\
\pm 2.0\end{array}$ \\
\hline & \multicolumn{2}{|c|}{$p<0.01$} & \multicolumn{2}{|c|}{$p<0.05(2)$} \\
\hline \multirow{2}{*}{$\begin{array}{l}\text { Lower subgroup length } \\
(\mathrm{mm})\end{array}$} & $\begin{array}{l}72.5 a \\
\pm 0.85\end{array}$ & $\begin{array}{l}68.9 \mathrm{~b} \\
\pm 1.65\end{array}$ & $\begin{array}{l}73.2 a \\
\pm 0.81\end{array}$ & $\begin{array}{l}68.9 b \\
\pm 1.16\end{array}$ \\
\hline & \multicolumn{2}{|c|}{$p<0.01$} & \multicolumn{2}{|c|}{$p<0.001$} \\
\hline \multirow[t]{2}{*}{$\begin{array}{l}\text { Upper subgroup length } \\
(\mathrm{mm})\end{array}$} & $\begin{array}{r}121.3 a \\
\pm 1.55\end{array}$ & $\begin{array}{r}108.7 b \\
\pm 2.93\end{array}$ & $\begin{array}{c}119.6 a \\
\pm 2.83\end{array}$ & $\begin{array}{r}112.9 b \\
\pm 3.80\end{array}$ \\
\hline & \multicolumn{2}{|c|}{$p<0.001$} & \multicolumn{2}{|c|}{$p<0.01$} \\
\hline
\end{tabular}

those of CP ST and SPCT (with the exception of the mean weight of CPST fish), being themselves larger than those of SPST (table 3). In the same way, the condition factor was higher for the CP CT group than for CPST and SPCT, being themselves higher than those of SP ST (table 3). Moreover, the mean lengths of each mode were higher for constant thermic and photoperiodic regimes (CP $>\mathrm{SP}, \mathrm{CT}>\mathrm{ST}$ ) (table 2).

After grading, the growth of the remaining fish ( figs. 4 and 5) varied according to the various regimes of the experiment (table 4): on September 7th (D219) the mean weights, lengths and condition factor of the $\mathrm{CP}$ fish were higher than those of groups exposed to SP. The mean weight and length of fish submitted to
Table 3. - Length, weight and condition factor (mean \pm standard error) for each condition (cumulated replicate) beforc grading. (1) data combined with CDT. The same letter represent a homogencous group for each parameter (statistical analysis: Kurskall-Wallis H test).

\begin{tabular}{cccc}
\hline Parameter & \multicolumn{3}{c}{ Condition factor } \\
\hline Length (mm) & CPCT (1) & $102.72 \pm 2.13 a$ & $p<0.001$ \\
& CPST & $94.96 \pm 1.99 b$ & \\
& SPCT (1) & $94.83 \pm 1.90 b$ & \\
Weight (g) & SPST & $86.49 \pm 1.67 c$ & \\
& CPCT (1) & $17.32 \pm 0.96 a$ & $p<0.001$ \\
& CPST & $12.94 \pm 0.76 a b$ & \\
& SPCT (1) & $13.18 \pm 0.73 b$ & \\
Condition factor & SPST & $9.19 \pm 0.49 c$ & \\
& CPCT (1) & $1.30 \pm 0.010 a$ & $p<0.001$ \\
& CPST & $1.24 \pm 0.009 b$ & \\
& SPCT (1) & $1.23 \pm 0.008 b$ & \\
& SPST & $1.19 \pm 0.008 c$ & \\
& & &
\end{tabular}

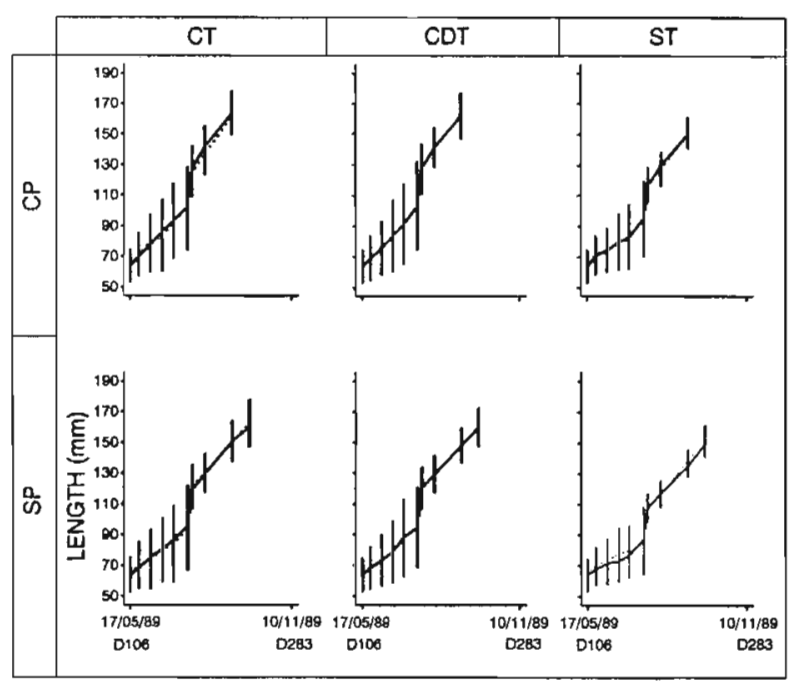

Figure 4. - Length $(\mathrm{mm})$ of salmon subjected to different conditions. T: temperature, $\mathrm{P}$ : photoperiod, $\mathrm{C}$ : constant, $\mathrm{S}$ : simulated. For CPCT, CPST, SPCT, SPST, the two curves show the replicate tanks.

CT and CDT did not differ significantly, but were superior to ST; differences were observed among the condition factors: the condition factor for CT (1.286) was higher than the one for CDT (1.247), but they were both similar to ST (1.264) (table 4).

During the transfer to seawater, biometric samplings were realized only for the SP fish. The mean weights and lengths of SPST were lower $(p<0.001)$ than those of SPCT and SPCDT that were similar [during the previous sampling on September 6th, the mean weights and lengths of SPCT and SP CDT were also similar $(p=0.170)]$. The condition factors of the various conditions were not significantly different $(p=0.157)$. 


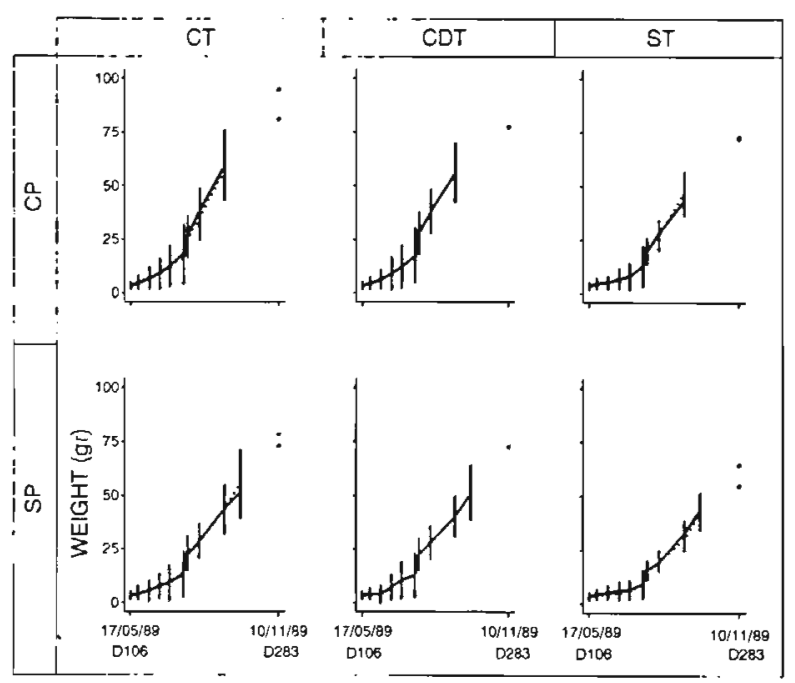

Figure 5. - Weight (g) of salmon subjected to different conditions. T: temperature, P: photoperiod, C: constant, S: simulated. The points represent the mean weight $(\mathrm{g})$ of each batch after transfer to seawater. For C.PC.T, CPST, SPCT, SPST, the two curves (and points) show the replicate tanks.

Table 4. - Length (mm), weight $(\mathrm{g})$ and condition factor (mean \pm standard error) of the upper mode (cumulated replicate) before transfer to seawater (Sept. 7th). See explanations rable 1.

\begin{tabular}{|c|c|c|c|c|}
\hline $\begin{array}{l}\text { Length } \\
(\mathrm{mm})\end{array}$ & $C T$ & CDT & $\mathrm{ST}$ & $P$ \\
\hline $\mathrm{CP}$ & $\begin{array}{c}162.9 a \\
+1.1\end{array}$ & $\begin{array}{c}162.0 a \\
+1.9\end{array}$ & $\begin{array}{c}150.6 b \\
+0.8\end{array}$ & $\begin{array}{c}157.0 a \\
+0.8\end{array}$ \\
\hline SP & $\begin{array}{c}150.8 a \\
\pm 1.2\end{array}$ & $\begin{array}{c}148.3 b \\
\pm 1.3\end{array}$ & $\begin{array}{c}136.3 c \\
\pm 0.7\end{array}$ & $\begin{array}{c}144.3 b \\
\pm 0.7\end{array}$ \\
\hline \multirow[t]{3}{*}{$\mathrm{T}$} & $156.8(a)$ & $154.3(a)$ & $143.9(b)$ & \multirow{3}{*}{$\begin{array}{c}\text { interaction } \\
\text { NS }\end{array}$} \\
\hline & \pm 1.0 & \pm 1.3 & \pm 0.7 & \\
\hline & \multicolumn{3}{|c|}{$p<0.001$} & \\
\hline $\begin{array}{l}\text { Wcight } \\
\text { (g) }\end{array}$ & CT & CDT & $S T$ & $\mathrm{P}$ \\
\hline $\mathrm{CP}$ & $\begin{array}{l}58.6 a \\
\pm 1.4\end{array}$ & $\begin{array}{l}56.2 a \\
\pm 1.8\end{array}$ & $\begin{array}{l}45.2 \mathrm{~b} \\
\pm 0.7\end{array}$ & \multirow{3}{*}{$p<0.00$} \\
\hline $\mathrm{SP}$ & $43.7 b$ & $40.4 b$ & $31.2 c$ & \\
\hline & \pm 1.1 & \pm 1.1 & \pm 0.5 & \\
\hline \multirow[t]{3}{*}{$T$} & $51.1(a)$ & $47.3(a)$ & $38.6(b)$ & \multirow{3}{*}{$\begin{array}{c}\text { interaction } \\
\text { NS }\end{array}$} \\
\hline & \pm 1.0 & \pm 1.2 & +0.6 & \\
\hline & \multicolumn{3}{|c|}{$p<0.001$} & \\
\hline $\begin{array}{l}\text { Condition } \\
\text { factor }\end{array}$ & $\cdots--$ & CDT & ST & $\mathrm{P}$ \\
\hline $\mathrm{CP}$ & $\begin{array}{l}1.334 a \\
\pm 0.012\end{array}$ & $\begin{array}{c}1.292 \mathrm{ab} \\
\pm 0.018\end{array}$ & $\begin{array}{l}1.308 a \\
\pm 0.007\end{array}$ & \multirow{2}{*}{$p<0.00 \mathrm{l}$} \\
\hline $\mathrm{SP}$ & $\begin{array}{l}1.247 b c \\
\pm 0.006\end{array}$ & $\begin{array}{l}1.220 c \\
\pm 0.014\end{array}$ & $\begin{array}{l}1.222 c \\
\pm 0.008\end{array}$ & \\
\hline \multirow[t]{3}{*}{$\mathrm{T}$} & $1.286(a)$ & $1.247(b)$ & $1.264(a b)$ & \multirow{3}{*}{$\begin{array}{c}\text { interaction } \\
\text { NS }\end{array}$} \\
\hline & \pm 0.007 & \pm 0.012 & \pm 0.006 & \\
\hline & & $p<0.0$ I & & \\
\hline
\end{tabular}

\section{Smoltification}

The gill $\left(\mathrm{Na}^{+}-\mathrm{K}^{+}\right)$-ATPase activity changed during the experiment and, for all the cases, values higher than $10 \mu \mathrm{m} \mathrm{Pimg}$ Prot. ${ }^{-1} \mathrm{~h}^{-1}$ have been observed. However, the evolution was different according to the

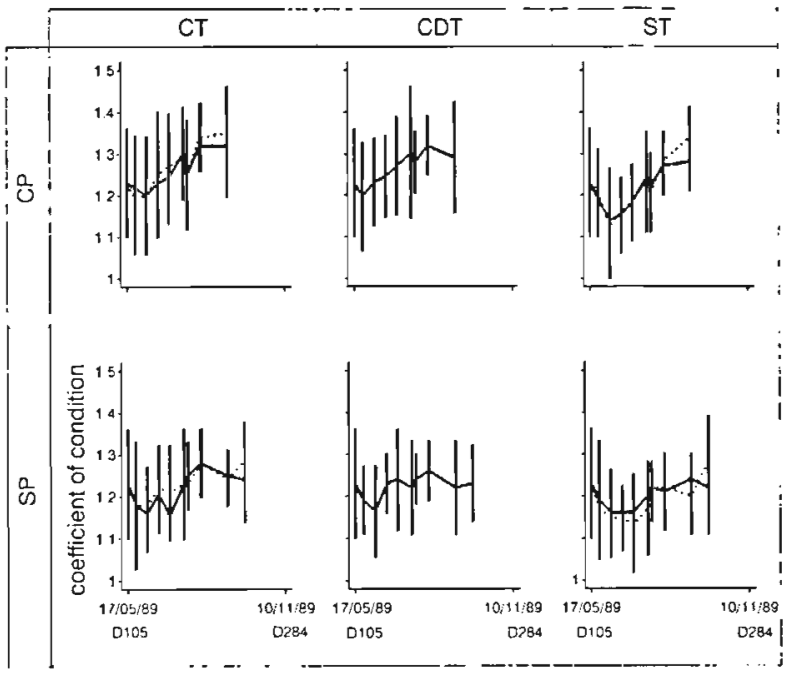

Figure 6. - Condition factors for the different conditions. T: temperature, P: photoperiod, C: constant, S: simulated. For CPCT, CPST, SPCT, SPST, the two curves show the replicate tanks.

conditions (fig. 7). With a constant photoperiod (CP), the evolution was best expressed by a second step model. A progressive photoperiod after a short "winter season" (SP) gave a very progressive evolution of the $\left(\mathrm{Na}^{+}-\mathrm{K}^{+}\right)$-ATPase. $A$ lincar model gave the best adjustement in this case. The final decrease of temperature to $13^{\circ} \mathrm{C}$ (CDT) was the only thermic condition that tended to modify the enzymatic activity: for the constant photoperiod the plateau remained for a longer time.

However, at any date, only the CPST was different from the other conditions: at the time of the first sampling (August 1st, D182), the replicates were heterogeneous; for both the following points, the $\left(\mathrm{Na}^{+}-\mathrm{K}^{+}\right)$-ATPase levels were higher than those of all the other conditions (fig. 7).

\section{Transfer to seawater}

The first transfers with a $35^{\circ} / 00$ salinity occurred on September 26th (D238) and October 11th (D253) of the first year of rearing for respectively the first and second replicate. Even if the gill $\left(\mathrm{Na}^{+}-\mathrm{K}^{+}\right)$-ATPase activities were similar for all conditions, after 48 hours the first transfer gave significant differences for osmotic pressures and chlorides: there was a photoperiodic influence and the SPST showed a less osmotic disturbance than CPCT (table 5). 3 weeks alter the transfer to seawater, the osmotic pressures and chlorides were similar for all the conditions and regimes. 


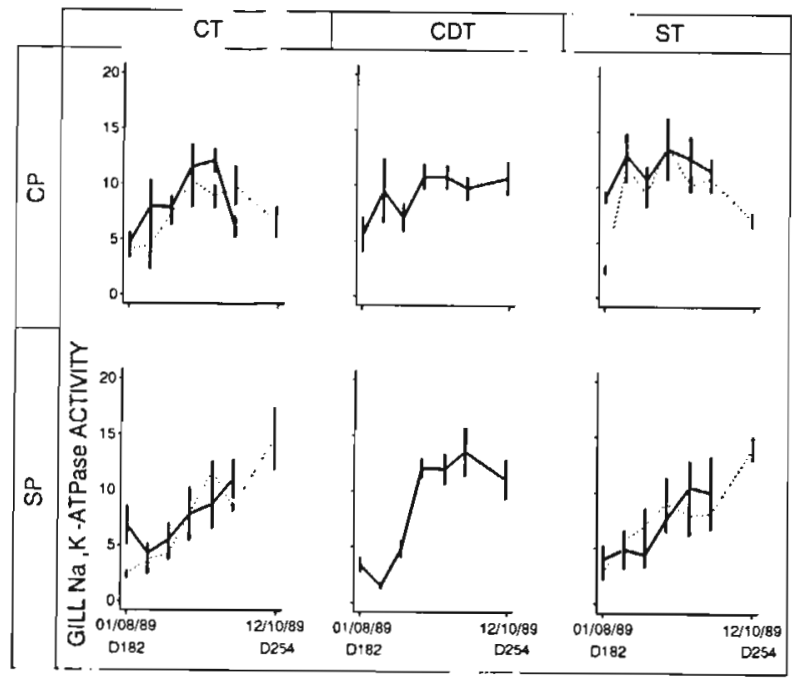

$$
\begin{aligned}
& \text { CPCT: } Y=2.922+0.305 X-0.003 X^{2}\left(R^{2}=0.856\right) \text {; } \\
& Y-3.736+0.464 X-0.077 X^{2}\left(R^{2}=0.649\right) \\
& \text { CPST: } Y=9.325+0.226 X-0.004 X^{2}\left(R^{2}=0.536\right) \text {; } \\
& Y=4.393+0.405 X-0.005 X^{2}\left(R^{2}-0.644\right) \\
& \text { SP C.T: } Y=4.642+0.104 \times\left(R^{2}=65.2\right) \text {; } \\
& Y-1.896+0.175 X\left(R^{2}=89.9\right) \\
& \text { SPST: } Y=0.146+3.1106 \times\left(R^{2}=87.1\right) \\
& Y=0.131+3.551 \times\left(R^{2}-86.3\right)
\end{aligned}
$$

Figure 7. - Changes in gill $\left(\mathrm{Na}^{+} \cdot \mathrm{K}^{+}\right)$-ATPase activity for the different conditions. T: temperature, P: photoperiod, C: constant, S: simulated. For CPCT, CPST, SPCT, SPST, the two curves show the replicate tanks. The regressive equations describe the cnzymatic activity (se'e text for explanations).

No mortality was observed during the first 15 days in seawater; after 7 weeks, the mortality for CPCT, CP ST, SPCT and SPST conditions were respectively $5.3 ; 15.5 ; 4.2 ; 1.3 \%$ of the initial number of transferred fish.

No mortality was observed during one month after the other batches had been transferred to seawater a fortnight later.

For each tank, the growth in salt water was quite similar to that previously obscrved in freshwater, after the grading (fig. 5) and not diflerent between the conditions and regimes (table 6).

\section{DISCUSSION}

Although some of the groups were reared with a high constant temperature of $16^{\circ} \mathrm{C}$, no disease or mortality appeared. The final mean weight obscrved in this case was higher than that obtained under the colder ST treatment (minimum: $8^{\circ} \mathrm{C}$ ), but no different from that obtained under the CDT treatment which had a lower $13^{\circ} \mathrm{C}$ constant temperature during the final phase of the experiment. These results suggest that under our rearing conditions and with the food used, the maximum growth rate would be between
Table 5. - Gill $\left(\mathrm{Na}^{+}-\mathrm{K}^{+}\right)-\Lambda$ TPase (with the mean weight of the analized fish) before transfer to seawater, osmotic pressure and plasma chloride after 48 hours in salt water $\left(35^{\circ} \%\right.$ salinity). T: lemperaturc;

\begin{tabular}{|c|c|c|c|c|}
\hline $\begin{array}{c}\text { Growth rate } \\
(\%)\end{array}$ & CT & ST & & \\
\hline $\mathrm{CD}$ & $0.63 a \pm 0.14$ & $0.73 a \pm 0.07$ & $0.68 \pm 0.07$ & \\
\hline$S P$ & $0.73 a \pm 0.02$ & $0.68 a \pm 0.21$ & $0.71 \pm 0.08$ & NS \\
\hline \multirow[t]{2}{*}{$\mathrm{T}$} & $0.68 \pm 0.06$ & $0.71 \pm 0.09$ & \multirow{2}{*}{\multicolumn{2}{|c|}{$\begin{array}{l}\text { interaction } \\
\text { NS }\end{array}$}} \\
\hline & \multicolumn{2}{|c|}{ NS } & & \\
\hline
\end{tabular}
P: photoperiod, C: constant, $S$ : simulated. The mean \pm standard crror are given. For each condition and each factor ( ) the same letter represents a homogeneous group.

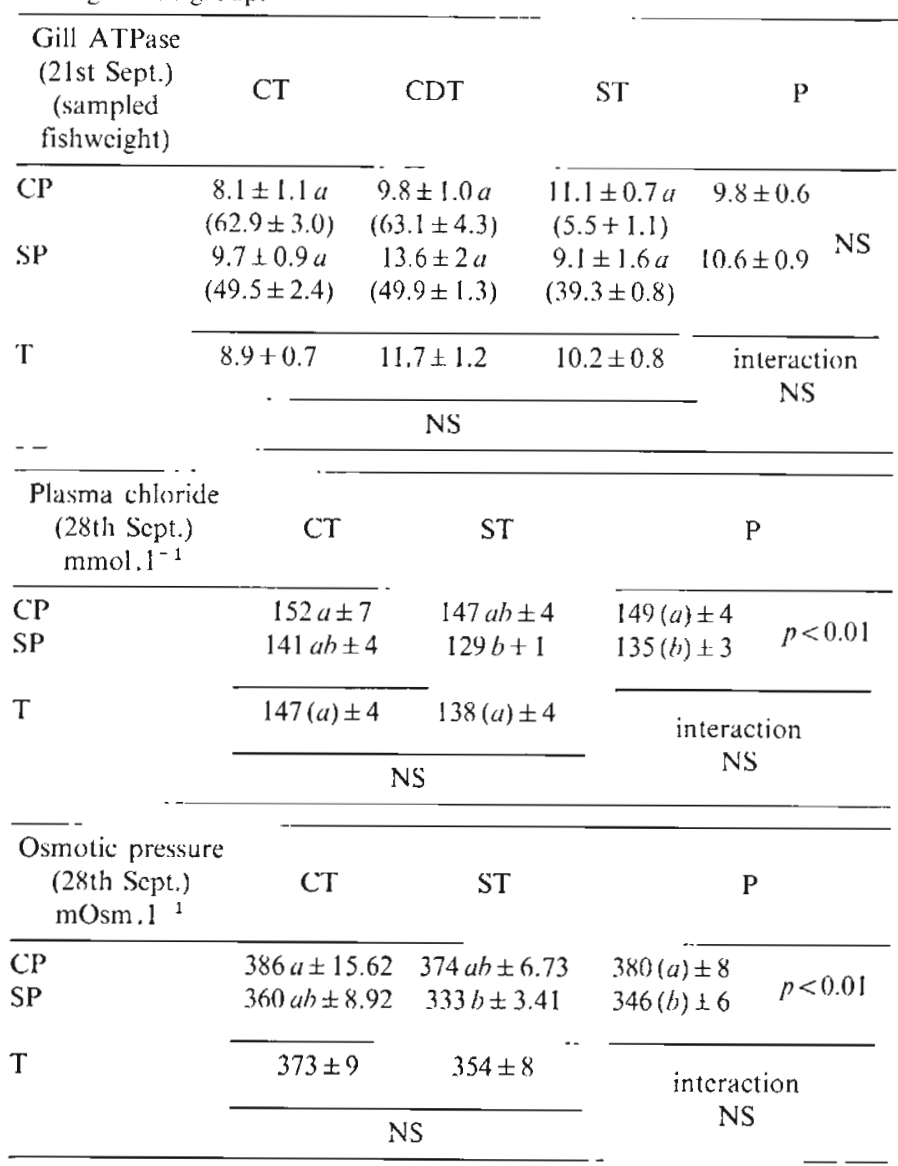

Table 6. - Growth rate (mean in \%/day \pm standard crror) during the first 17 days after transfer 10 seawater. T: temperature, P: photoperiod, C: constant, S: simulated.

13 and $16^{\circ} \mathrm{C}$, as generally found for the Atlantic salmon (Foda and Henderson, 1977; McCaulcy and Casselman, 1980), but slightly below the temperature $\left(16^{\circ} \mathrm{C}\right)$ proposed by Knutsson and Grav (1976). The natural shortened simulated photoperiod regime (SP) had a negative influence on growth (initial growth rate, mean length and weight before grading, upper and lower group mean length, final length and weight) 
compared to the constant photoperiod regime (CP). In the latter case, illumination duration was higher than in the other case and authorized the best growth as obtained by Clarke et al. (1981) on coho salmon or McCormick et al., 1987; Villarreal et al., 1988, and Bjornsson et al., 1989 on Atlantic salmon: an extended day length can stimulate the pituitary axis and, subsequently, growth (Komoudjian et al., 1989). However, this author, working with a continuous artificial daylight, observed in his own experimental condition that the influence does not persist more than 3 months. In the same way, McCormick et al. (1987) showed that the weights obtained after a complete freshwater cycle in a natural photoperiodic regime or with continuous daylight are similar. In these 2 cases, it is possible that the lack of alternating light/dark during a long period leads to a negative eflect unlike in our situation where alternance exists. Generally, the relative influence of tempcrature and photoperiod is difficult to establish (Clarke et al., 1981). However, in our experiment, the weight and length observed in the two conditions SPCT and CPST [i.e. "constant regime of one factor ( $\mathrm{P}$ or $\mathrm{T}) \times$ simulated shortened regime of the other factor (T or P)"] were similar, and there was an intermediate value between the cases where the factor time-courses were the same (CPCT and SPST). This suggests, in spite of the temperature differences (and including the smoltification phase that represents an important part of the total rearing period), that the photoperiod could have a significant influence on the growth, possibly of the same magnitude as temperature.

As generally observed in the first autumn of the biological cycle of Atlantic salmon by several authors (Thorpe, 1977; Bailey et al., 1980; Kristinsson et al., 1985; Skilbrei, 1988; Stefansson et al., 1989), a heterogeneous individual growth appeared in all our experimental groups and led to a bimodal structure of the populations even when the photoperiod and temperature were constant. This phenomenon results from an acceleration of the individual growth (Kristinsson et al., 1985) when the fish reach a given size (Skilbrei, 1991) dependent on their genetic origin (Skilbrei, 1988) and under the control of environmental factors like photoperiod (Stewart et al., 1990; Skilbrei, 1991). During our experiment, the fish reached a size sufficient for initiating this process very early (from June of the first ycar of rcaring), much earlier than generally observed in Scotland, Norway, Canada by the above mentioned authors or in natural conditions in France (Gaignon, 1987).

The lowest ST growth rate led to a delayed length frequency segregation ( $f$ ig. $3 \mathrm{~B}$ ), with no effect on the upper subgroun percentages which were similar for CT and ST. This confirms the recent lindings of Skilbrei (1991) who showed that temperature has no effect on length frequency distribution. Conversely, the percentages of the upper subgroup were higher for the constant photoperiodic regime (CP) than for the simulated one as always observed by the authors studying the influence of photoperiodic regimes: an extension of received daylight would allow more fish to reach the initial size at which the fish enter the upper modal subgroup (Saunders et al., 1987; Villarreal et al., 1988; Saunders et al., 1989; Stefansson et al., 1989; Stewart et al., 1990). However, in our case, an extended period of individual increased growth rate would not exist for C.P: the length frequency segregation appeared at the same time for CP and SP. The lack of individual branding does not allow one to know if the initial size at which the growth rate increases is similar for all the conditions, nor if the growth rate for a particular length frequency is different according to the regimes (Stewart. 1990).

The upper-mode fish initiate their smoltification during their first year of life and this confirms that, even in our experimental situation, these fish are potential smolts as observed on the normal production cycle of 15-17 months (Thorpe, 1977; Thorpe ot al., 1980; Kristinsson et al., 1985; Bæuf ('t al., 1985).

The smoltification began very early: in all the cases there was an important increase of gill $\left(\mathrm{Na}^{+}-\mathrm{K}^{+}\right)$ATPase before mid September of the first year of rearing (or after less than 230 days or 9 months of feeding); the condition CP ST (constant photoperiod) gave a high level of enzymatic activity during the first fortnight of August (D 200 or 7 months). Hoar (1988) after Eriksson and Lundqvist (1982) concluded that, when there is no variation of the environmental factors (constant temperature: $11^{\circ} \mathrm{C}$; day length: 12 hours), change in the body's silvery coloration, darkening of the fin margins, variation of the condition factor and of the growth rate show the existence of an endogenous rhythm with a 1()-month period. The external factors are considered, in natural conditions, as a "brake" on this rhythm and in controlled conditions as a "zietgeber" of the development. In our experiment, the absence of photoperiod variations (CPCT condition for example) does not prevent the smoltification that starts after 7 months of feeding. The growth rates obtained here with more favourable temperature and pholoperiod than the ones by Eriksson and Lundquist are probably the reason for precocious smoltification. This shows the importance of the external factors and, among these, the level of temperature, without thermic variation, on all the process leading to the "First" smoltilication.

The gill $\left(\mathrm{Na}^{+}-\mathrm{K}^{+}\right)$-ATPase activity evolution is photoperiod-dependent. A progressive increase of the day length has a progressive "driving" effect, giving here a lincar answer on Atlantic salmon as already shown by Clarke et al. (1985) and Clarke et al. (1981) on Pacific salmon. The increase of the cnzymatic activity with a constant photoperiod, also obtained by Duston and Saunders (1990 b), shows that an increase of the day length is not necessary to initiate the smoltification. The activation can result from the larger size and so from the best growth rate of these 
fish. A size threshold, as existing before leading to the bimodal structure of the population, might occur under some favourable external parameters. As suggested by Saunders et al. (1989), one can think that the temperature has a positive influence, but these authors consider that $10^{\circ} \mathrm{C}$ is a "high" temperature which can be beneficial. Furthermore, as already mentioned by Johnston and Saunders (1981), the temperature used $\left(16^{\circ} \mathrm{C}\right)$ does not seem to be a limiting factor as estimated by Duston and Saunders (1990a, b): in this last case, the thermic variations probably have a more negative effect than the absolute levels. On the other hand, a final decrease of the temperature $\left(13^{\circ} \mathrm{C}\right)$ has a positive influence on the extension of the high level of the $\left(\mathrm{Na}^{+}-\mathrm{K}^{+}\right)$-ATPase activity as already showed on Atlantic salmon (Johnston and Saunders, 1981), steelhead trout and coho salmon (in Wedemeyer et al., 1981). The highest temperatures do not tend to advance the physiological process as observed by Johnston and Saunders (1981).

In all the tanks, the maximum gill $\left(\mathrm{Na}^{+}-\mathrm{K}^{+}\right)$ATPase activily of the fish was about 12$15 \mu \mathrm{m}$ Pimg Prot. ${ }^{-1} \mathrm{~h}^{-1}$. These values are generally observed on the upper-mode fish showing a good adaptive capacity to high salinity (Bxuf, 1987) but never reached by lower-mode fish having a low tolerance to high salinity. However, these values are slightly lower than the absolute values registered on $1^{+}$ smolts reared in natural conditions (Bœuf et al., 1985) - with the same analytical methods. This suggests that the physiological process ending the smoltification state is not completely achievcd. The lack of decreased condition factors ( $f$ ig. 6) also confirms this point (adapted from Farmer et al., 1978; McCormick et al., 1987), even if we may admit that the high temperatures tend to favour an increase of the condition factor (Clarke et al., 1981; Johnston and Saunders, 1981) and that the lack of normal winter duration does not allow a sufficient decrease in the weight growth rate compared with the length growth rate (Bjornsson et al., 1989).

These absolute levels cannot be connected either with the long-tcrm mortality or with the differences between the osmotic disturbance observed after transfer into the high salinity salt water for each condition. The lower osmotic disturbance is registered with the simulated photoperiod (SP). In the same way, Bjornsson et al. (1989) and Clarke et al. (1989) showed the beneficial influence of the presence of short day lengths. Moreover, the lack of significant difference between the two thermic conditions of the simulated photoperiod (table 8 ) masks physiological differences: there was no important osmotic modification $\left(333 \mathrm{mOsm} .1^{-1}\right)$ for SP ST in comparison with that of SPCT $\left(360 \mathrm{mOsm} .1^{-1}\right)$. We suggest, as already show by Johnston and Saunders (1981) in different experimental conditions from ours, that the progressive increase of photoperiod and temperature, permitting a "progressive" smoltification, favours, in our case, the high-salinity tolerance, even if we way consider that, according to the usual criterion, smoltification is not completely achieved. Bœuf et al. (1990) also obtained excellent survival and growth after a transfer to seawater following a growth hormone stimulation with low level of gill $\left(\mathrm{Na}^{+}-\mathrm{K}^{+}\right)$-ATPase activity (6.4) but increasing very quickly $(\times 2$ in 12 days). The discordance between the level of the enzymatic activity and the short-term high-salinity tolerance has also been recently observed by Saunders and Harmon (1990) with a precocious photoperiodic control. The large size of the fish (Johnston and Saunders, 1981; Duston and Saunders, 1990; Saunders and Harmon, 1990) and the high growth rate (Ewing et al., 1980) may have eased the acquisition of the euryhalinity status without, however, permitting a high level of gill ATPase activity.

After three weeks in $35 \%$ salt water, the osmotic pressure and the growth of the fish were "normal" and confirmed that smoltification had been obtained after 7-8 months of rearing. These results arc not concordant with the actual knowledge of many authors, $i . e$. it is necessary to have a natural increasing photoperiod over several months, permitting an "accomplished" smoltification and then a high-salinity tolerance and marine growth capacities (Isaksson, 1985; Saunders et al., 1985; McCormik et al., 1987; Stefansson et al., 1989; Saunders et al., 1985). However, the growth obtained during the first weeks of the marine phase does not seem to be dependent on the experimental conditions: as the large size of the fish could facilitate the high-salinity tolerance, it could have an influence on the growth after transfer to seawater.

In conclusion,

- The Atlantic salmon freshwater phase duration is essentially dependent on the growth and therefore on the level of the environmental factors (temperature). Its duration can vary, even with constant level of the external factors. The triggering of the smoltification is probably linked to the size and the growth rate at a given time.

- In these conditions, it is possible to obtain Atlantic salmon smolts with a good high-salinity tolerance after a short freshwater phase (7 to 8 months), quite different from the duration of the natural biological cycle.

- Under rearing conditions, when the production factor levels are very far from those observed in natural conditions, the absolute levels of the usual smoltification criteria may be discussed: the necessity of an accomplished smoltification can be compensated by a "smoltification and growth dynamics".

In spite of the interest of these results for Atlantic salmon smolt production, we must keep in mind the practical constraints for the transfer of such fish to seawater (artificial rearing and natural conditions are out of phase), and the possible effect on the long-term performances (growth and precocious maturation), which have not been assessed. 


\section{Acknowledgements}

We thank B. Petton, Y. Normant, A. Le Roux, A. Sévère for technical assistance, G. Beul and Y. Harache for constructive criticisms of the manuscript and help with translation, and $N$. Rossignol who typed the paper.

\section{REFERENCFS}

Bailey J. K., R. L. Saunders, M. I. Buzeta, 1980. Influence of parental smolt age and sea age on growth and smolting of hatchery-reared Atlantic salmon (Salmo salar). Can. J. Aquat. Sici., 37, 1379-1386.

Bjornsson B. Th., H. Thorarensen, T. Hirano. T. Ogasawara, J. B. Kristinsson, 1989. Photoperiod and temperature alfect plasma growth hormone levels, growth, condition factor and hypoosmoregulatory ability of juvenile Atlantic salmon (Salmo salar) during parr-smolt transformation. Aquaculture, 82, 77-91.

Bæuf G., 1987. Contribution à l'étude de l'adaptation à l'eau de mer chez les Poissons Salmonidés. Détermination de critères de smoltification par mesures de l'activité $\left(\mathrm{Na}^{+}-\mathrm{K}^{+}\right)$-ATPase des microsomes de la branchie et des hormones thyroïdiennes plasmatiques. Thèse dr. Etat, Univ. Bretagne Occidentale, Brest, 319 p.

Bouf $G ., 1992$. Salmonid smolting: a pre-adaptation to the oceanic environment. Fish Ecophysiology, J. C. Rankin. F. B. Jensen Eds., Chapman and Hall, London, 20 p. (in press).

Bow G. G. Y. Harache, 1982. Critcria for adaptation of salmonids to high salinity seawater in France. Aquaculture, 28, 163-176.

Bouf G., A. Le Roux, J.-L. Gaignon, Y. Harache, 1985. Gill $\left(\mathrm{Na}^{+}-\mathrm{K}^{+}\right)$-ATPase activity and smolting in Atlantic salmon (Salmo salar L.) in France. Aquaculture, 45, 7381.

Bouf G., P. Prunet, P. Y. Le Bail, 1990. Un traitement à l'hormone de croissance peut-il stimuler la smoltification du saumon atlantique? C. R. Acad. Sici. Paris, 310, Series III, 75-80.

Bceuf G., A. Medina, 1990. Chile: the promise and the problems. World Aquac., 21, 14-24.

Brauer E. P., 1982. The photoperiod control of coho salmon smoltification. Aquaculture, 28, 105-111.

Cassie R. M., 1954. Some uses of probability paper in the analysis of size frequency distributions, Aust. J. Mar. Freshw. Res., 5, 513-522.

Clarke W. C., J. E. Shelbourn, J. R. Brett, 1981. Ellect of artificial photoperiod cycles, tempcrature and salinity on growth and smolting in underyearling coho (Oncorhynchus kisutch), chinook (O. tsharytscha) and sockeye (O. nerka) salmon. Aquaculture, 22, 105-116.

Clarke W. C., L. Lundquist, L. O. Eriksson, 1985. Accelerated photoperiod advances seasonal cycle of seawater adaptation in juvenile Baltic salmon. Salmo salar L. $J$. Fish Biol., 26, 29-35.

Clarke W. C., J. E. Shelbourn, T. Ogasawara, T. Hirano, 1989. Effect of initial daylength on growth, seawater adaptatibility and plasma growth hormone levels in underycarling coho, chinook and chum salmon. Aquacuiture, 82, 51-62.

Duston J., R. L. Saunders, 1990 a. Control of the timing of smoltilication in Atlantic salmon: endogenous rhythms and environmental factors. I $n$ : Proceedings of CanadaNorway finlish aquaculture workshop. Can. Tech. Rep. Fish. Aquat. Sci., 1761, 99-11)5.

Duston J., R. L. Saunders, 1990h. The entrainment role of photoperiod on hypoosmoregulatory and growth-related aspects of smolting in $\Lambda$ tlantic salmon (Salmo salar). Can J. Yool., 68, 707-715.

Duston J., R. L. Saunders, D. E. Knox, 1991. Effects of increases in freshwater temperature on loss of smolt characteristics in Atlantic salmon (Salmo salar). Can. J. Fish. Aquat. Sit., 48, 164-169.

Friksson L. O., H. Lundqvist, 1982. Circannual rhythms and photoperiod regulation of growth and smolting in Baltic salmon (Salmo salur L.). Aquaculture, 28, 113-121.

Ewing R. D., H. J. Pribble, S. L. Johnson, C. A. Fustish. J. Diamond, J. A. Lichatowich, 1980. Influence of size. growth rate and photoperiod on cyclic changes in gill $\left(\mathrm{Na}^{+}-\mathrm{K}^{+}\right)$-ATPase Activity in chinook salmon (Oncrorhynchus tshanytscha). (an. J. Fish. Aquat. Siri., 37, 600605.

Farmer G. J., J. A. Ritter, D. Ashlield, 1978. Seawater adaptation and parr-smolt transformation of juvenile Atlantic salmon, Salmo salar. J. Fish. Res. Board Can., $35,93-100$.

Foda A., T. K. Henderson, 1977. Effect of water temperature on rate of embryonic development, growth and survival of Atlantic salmon (Salmo salar), CIEM C.M. 1977/M:31, $7 \mathrm{p}$.

Gaignon J.-L., 1987. L’élevage des juvéniles de saumon atlantique (Salmo salar). Piscicult. Fr., 90, 5-56.

Hasselblad V., 1966. Estimation of parameters for a mixture of normal distributions. Technometrics. 8, 432-444.

lloar W. S.. 1988. The physiology of smolting salmonids. In: Fish Physiology, Vol. XI, The Physiology of developing fish Part B, Viviparity and posthatching juveniles. Academic Press, 275-342.

Isaksson $\Lambda$. . 1985. The production of one-year smolts and prospects of producing zero-smolts of Atlantic salmon in Iceland using gcothermal resources. Aquaculture, 45, 305319.

Johnston C. E., R. L. Saunders, 1981. Parr-smolt transformation of ycarling Atlantic salmon (Salmo salar) at several rearing temperatures. Can. J. Fïsh. Aquat. Sci.. 38. 1189-1198.

Knutsson S., T. Grav, 1976. Seawater adaptation in Atlantic salmon (Salmo salar L.) at different experimental temperatures and photoperiods. Aquaculture, 8, 169-187. 
Komourdjian M. P., J. C. Fenwick, R. [.. Saunders, 1989. Endocrine-mediated photostimulation of growth in Atlantic salmon. Can J. Zool., 67, 1505-1509.

Kristinsson J. B., R. L. Saunders, A. J. Wiggs, 1985. Growth dynamics during the development of bimodal length frequency distribution in juvenilc Atlantic salmon (Salmo salar L.). Aquaculture, 45, 1-20.

Lasserre P., G. Beuf, Y. Harache, 1978. Osmotic adaptation of Oncorhynchus kisutch Walbaum. I-Seasonal variations of gill $\left(\mathrm{Na}^{+}-\mathrm{K}^{+}\right)$-ATPase aclivity in coho salmon, $O$ age and yearling, rearcd in freshwater. Aquaculture, 14, 365-382.

McCormick S. D., R. L. Saunders, E. B. Henderson, P. R. Harmon, 1987. Photoperiod control of parr-smolt transformation in Atlantic salmon (Salmo salar): changes in salinity tolcrance, gill $\left(\mathrm{Na}^{+}-\mathrm{K}^{+}\right)$-ATPasc activity and plasma thyroid hormones. Can. J. Fish. Aquat. Sci., 44. 1462-1468.

McCauley R. W., J. M. Casselman, 1980. The final prefercndum as an index of the temperature for optimum growth in fish. In: Symposium EIFAC, Stavanger, 18 p.

Prouzet P., M. Jćzćquel, 1983. Caractéristiques des populations de saumon atlantique (Sulmo salar L.) capturécs à la ligne sur l'Elorn (Rivière de Bretagne Nord) durant la période 1974-1981. Bull. Fr. Piscic., 289, 94-11.

Sachs L., 1984. Applied Statistics, A handbook of techniques, Springer Verlag, N. Y., 707 p.

Saunders L. R., P. R. Harmon, 1990. Influence of photoperiod on growth of juvenile atlantic salmon and development of salinity tolerance during winter-spring. Truns. Am. Fish. Soc., 119, 689-697.

Saunders R. L., E. B. Henderson, 1988. Effects of constant day length on sexual maturation and growth of Atlantic salmon (Salmo salar) parr. Can. J. Fish. Aquat. Sci., 45, $60-64$.

Saunders L. R., E. B. Henderson, P. R. Harmon, 1985. Effects of photoperiod on juvenile growth and smolting of Atlantic salmon and subsequent survival and growth in sea cages. Aquaculture, 45, 55-66.

Saunders R. L., E. B. Henderson, P. R. Harmon, 1987. Extended daylength during autumn enhances growth of juvenile Atlantic salmon. Can. J. Zoot, 67.
Saunders R. L., J. L. Specker, M. P. Komourdjian, 1989. Effects of photoperiod on growth and smolting in juvenilc Allantic salmon (Salmo salar). Aquaculture, 82, 103 117.

Simpson T. H., 1985. Epilogue. Aquatulture, 45, 395-398.

Skilbrci O. T., 1988. Growth pattcrn of pre-smolt Atlantic salmon (Salmo sular L.): the percentile increment method (PIM) as a new method to estimate length-dependent growth. Aquaculture, 69, 129-143.

Skilbrei O. T.. 1991. Importance of threshold length and photoperiod for the development of bimudal length-frequency distribution in Atlantic salmon (Salmo salar). Can. J. Fish. Aquat. Sici., 48. 2163-2172.

Stefansson S. O., G. Nacvdal, T. Hansen, 1989. The influence of three unchanging photoperiods on growth and parr-smolt transformation in Atlantic salmon, Salmo salar L. J. Fish Biol., 35, 237-247.

Stefansson S. O., B. Th. Bjornsson, T. Hansen, C. Haux, G. L. Taranger, R. L. Saunders, 1991. Growth, parrsmolt transformation, and changes in growth hormone of $\Lambda$ tlantic salmon ( $S a / m o$ salar) reared under different photopcriods. Can. J. Fish. Aquat. Sci., 48, 2100 -2108.

Steward M. W., R. L. Saunders, 1990. Effects of extended daylength on autumn growth dynamics of juvenile Atlantic salmon, Salmo salar, Can. J. Fïsh. Aquat. Sci., 47, 755-759.

Thorpe J. E.. 1977. Bimodal distribution of length of juvenile Atlantic salmon (Salmes salar L.) under artilicial rearing conditions. J. Fïh Biol., 11, 175-184.

Thorpe J. E., R. I. G. Morgan, 1980. Time of divergence of growth groups between potential $1+$ and $2+$ smolts among sibling Atlantic salmon. J. Fish Biol., 17, 13-21.

Tomlinson P., 1970. Program NORMSEP-Normal distribution separator. In: Abramson N. J., FAO Fish. Techn. Pap., 101: computer programs for fish stocks assesment.

Villarreal C. A., J. E. Thorpe, M. S. Miles, 1988. Influence of photoperiod on growth changes in juvenilc Atlantic salmon, Salmo salar L. J. Fish Biol., 33, 15-30.

Wedemeyer G. A., R. L. Saunders, W. C. Clarke, 1981. The hatchery cnvironment required to optimize smoltification in the artificial propagation of anadromous salmonids. I $n$ : Proceedings of the Bio-engineering Symposium for fish culture, Traverse City Michigan, 16-18 Oct. 1979, L. J. Allen, E. C. Kinney Eds., 6-20. 